\title{
Reference of Statement in the Discourse
}

\section{Vladimir Anatolyevich Burtsev}

\author{
Institute of Philology, Department of Linguistics and Documents Study, Yelets State Bunin University \\ 28 Kommunarov Str., Yelets, Lipetsk Region, 399770, Russian Federation; E-mail: ivburcev@yandex.ru
}

Doi:10.5901/mjss.2015.v6n5s4p146

\begin{abstract}
The article studies the possibilities of describing the mechanism of reference in terms of statement making. The concept of adsubjectification is used, which allows introducing the mechanism of reference in the discourse as a relation of subordination of statement of the speaker to the statement of the other subject functioning in the current statement as unapproved predication. Adsubjectivation is examined on the material of sentences with non-propositional meaning. All material was abstracted from the texts of Russian Orthodox sermons of 19-20 centuries. Sermons are described precisely as an open set, and not as a specific speech work. The article shows that virtually all highly productive statements in sermons are referred to only one ontological entity - the fact. Referential properties of statements in the discourse are not connected with the pragmatic context and the subject of speech activity as a bearer of certain psychological (will, emotions, opinions) characteristics and are explained in terms of an act of statement making by the concept of adsubjectification.
\end{abstract}

Keywords: reference, statement, statement making, discourse, speaker, non-propositional meaning, adsubjectification, speech act, ascriptive, pre-ascriptive, semantic acceptability.

\section{Introduction}

\subsection{Introduction of the Problem}

Issues of reference are very important. They affect the fundamental parts of the semantics of sentence (and statement): the formation of the sentence's meaning, its communicative organization, relation to the context, language means of designation of the observed phenomena, etc. (Arutiunova, 1982).

In linguistic semantics, the reference means the relations between the speaker and the fact of what he says in a particular case (Lyons, 2003). The classificatory aspect of the reference has two sides: the semantic reference and the speaker's reference (Linskii, 1982). We are interested in the speaker's reference, which, according to the traditional view, is due to the context and intention of the author of the speech. Development of the speaker's reference played a significant role in the development of the main direction of pragmatic research related to the subjectivity of the statements, as well as linguistic semantics understood as an area of research that includes the study of not only sentences, but also statements' meaning (Lyons, 2003).

However, this approach is still incomplete, as it overlooks the fact that the structure of almost any resulting statement includes expressions, the reference of which is independent of the speaker; those are the parts of statements expressing non-predicated propositions-nominalizations, subordinate parts, comparative structures, and some others (all of them involve a positional model of the sentence, that is they may take a position of the sentence and become the sentence (Lomtev, 1958)). This approach also makes no mention of the possible interaction between the two referential spheres of the statement: the speaker's references and the references of the subject of non-predicated propositions.

\subsection{Importance of the Problem}

This article studies the side of the statement reference that manifests itself in the interaction of the speaker's reference and the reference of the subject of the unapproved predicate group. It is believed that the semantic result of cooperation between the two referential spheres of the statement is not the author's subjectivity, but what can be called adsubjectification, subordination of the speaker to the subject of non-predicated proposition due to the reference of nonpredicated proposition to the fact specific for the discourse-as to one of the three (propositions, events, facts) types of ontological objects. Adsubjectification and necessary reference to the fact are treated in this paper as the phenomena defining the discourse (in its distinction from speech and communication) as an integral part of the synchronic state of any 
national language.

Adsubjectification is examined on the example of the material, which would seem to contradict the very notion of adsubjectification: these are sentences with non-propositional (non-expressible conditionally-truthfully (Lyons, 2003)), subjective components of the meaning. In particular, simple - imperative sentences with the predicate "future perfect", with the "modal operators" (Zeitlin, 1990) of necessity (such as should, need, required, and others) are considered, as well as compound conditional and correlative (pronominal-correlative) sentences.

All material was abstracted from the texts of Russian Orthodox sermons of 19-20 centuries. Sermons are described precisely as an open set, and not as specific speech works. Therefore, conclusions, which we hope to be able to characterize the language of all speech works belonging to the genre of Russian Orthodox preaching, as well as to predict in advance, which peculiarities of the statement semantics provide originality of the discourse of preaching, are formulated in the paper as the final judgment.

\subsection{Relevant Scholarship}

The problem of the subject is stimulated by the theory of statement of Benveniste (2002). Currently, this theory enjoys the widest recognition in the discussion of subjectivity in the language. It includes issues of speech acts (Strawson, 1986; Searle et al., 1986), locutionary activity (Paducheva, 1996), reference (Strawson et al., 1982; Paducheva, 1985 Arutiunova, 1982, 2002), modality (The theory of functional grammar, 1990) and several others (Pereverzev, 1998; Savova, 2012; Sokolovskaia, 1993). Despite the existence of different versions of the theory of statement subjectivity, as well as a significant diversity in the use of the term "subject"-the subject as an individual, as a linguistic personality, the subject of the facts reported, the subject of parenthetical inclusions, the subject of evaluation (Demiankov, 1981, 1983; Piers, 1983; Stepanov, 1981; Chimik, 1990; Jacobson, 1972)-there are stable overall associations and connotations in determining the subject matter of subjectivity in the language: it is the study of the ways of the speaker's expression of himself in the active communicative function of a speech sender. The expression of subjectivity is understood as bridging the gap between the speaker and the subject of the sentence (Stepanov, 1981; Chimik, 1990). In this regard, "subjectivity ... can be found in the content of the subject of the fact reported, in predicates correlated with it, in the subject distributors of predicate-verbs and whole grammatical basis of the sentence. Subjective functions of this kind represent subjective meanings primarily using personal pronouns and personal verb forms-the core exponents of the functional-semantic category of personality" (Chimik, 1990).

We cannot fail to agree that subjectivity is felt in varying degrees in every statement. However, in the light of the stylistic, socio-cultural, referential and other restrictions (for example, in the narrative (Paducheva, 1996) or constructions (Rachilina, 2010)) of the use of the language, it is still disputable whether it is always the subject of the statement that is responsible for provision of contextualization of a sentence, adequate situation, in which a specific sentence is used. In this case, we can refer to a range of diverse phenomena (polyphony in the texts) posing a problem from the point of view of the theory of statement subjectivity. These include indirect speech, pseudo-descriptions (Wierzbicka, 1978), allusions (Authier-Review, 1999), nominalization (Serio, 1999), development (in communication) of phrasal expressions (Burtsev, 2013) and syntactic phrasems (Kopotev, 2008), the potential speech-act properties of the sentences in discourse, the use of complex adverbial sentences (Davison, 1986; Pereverzev, 1998; Burtsev, 2014), some syntactic relations (topics, definiteness, given) and presuppositions.

Not all these things, of course, can be considered in this paper. However, it seems to be useful to say a few words concerning the potential speech-act properties of the sentences. This phenomenon is closely related to the topic of this paper. It seems to reveal a certain regular referential connection between the grammatical meaning of a sentence and the nature of the speech act most clearly, which the speaker can and should make when using this type of sentences as their statements in the discourse. In the following examples (1)-(4) and in the examples of their transforms, the speechact properties of explanatory sentences in the discourse of the Russian Orthodox sermon are shown.

In the language of sermons, based on explanatory sentences, almost without exceptions, statements are produced, in which the subordinate clauses behave as subordinate predications with factive verbs, i.e. the subordinate part is presented as the true one itself (Karttunen, 1985). This is illustrated by sentences (1)-(4) and their conversions (1a-4a):

(1) From this, it is clear that the beneficial power of the law extends to every human being (Menetrov, 1905).

(1a) The beneficial power of law extends to every human being.

(2) And now, the Apostle Paul urges the early Christians, and all of us ... to believe that all the difficulties experienced

for the sake of Christ will be marked by God and awarded in the blissful eternity (Vladimir (Ikim), 2009). 
(2a) All the difficulties experienced for the sake of Christ, will be marked by God and awarded in the blissful eternity.

(3) We ... easily forget that we were created and sent into this world by the Lord for the eternal life (Nicholas, 1950).

(3a) We were created and sent into this world by the Lord for the eternal life.

(4) We see that many of the sinners, having done the repentance, have reached essential Christian perfection (St. Ignatius Bryanchaninov, 2011).

(4a) Many of the sinners, having done the repentance, have reached essential Christian perfection.

Firstly, almost all of expressions (1a-4a) are similar to the expressions with reference to a fact. Examples (1a-4a) allow presenting the subordinate groups in the form of both types of nominalization, both full and partial (possible stylistic roughness, for example, when converting (3a) are considered permissible to ignore). Compare: Achieving by many sinners ... of the highest degree of Christian perfection. Such transformations show that these expressions have reference to the fact, but not to an event or proposition.

Secondly, performative verb synonymous to factive predicates can be determined based on the similarity of selectional and semantic properties of factive predicates and performatives. It is the verb "to communicate," which contains the component "to know" in its semantic structure (Wierzbicka, 1985: 255), and in many contexts can replace the factive predicate without disrupting the semantic effect of the original expression.

(1b) I communicate that the beneficial power of the law extends to every human being.

(2b) I communicate that all the difficulties experienced for the sake of Christ, will be marked by God and awarded in the blissful eternity

(3b) I communicate that we were created and sent into this world by the Lord for the eternal life.

(4b) I communicate that many of the sinners, having done the repentance, have reached essential Christian perfection.

Thirdly, in the replacement of the factive predicate with the expositive considerlassume (Austin, 1986: 128), the described relationship disappears: the predicative parts do not assume truthfulness of their propositions.

(1c) I consider (assume) that the beneficial power of the law extends to every human being.

(2c) I consider (assume) that all the difficulties experienced for the sake of Christ, will be marked by God and awarded in the blissful eternity

(3c) I consider (assume) that we were created and sent into this world by the Lord for the eternal life.

(4c) I consider (assume) that many of the sinners, having done the repentance, have reached essential Christian perfection.

Expressions (1c)-(4c) have reference to the proposition, since they have direct subjective connotations. From this, we can conclude that the statements of this type in the discourse of preaching are not possible, as the recipient must then believe the intelligent concepts of the particular speaker, rather than the dogmas of the church.

Thus, only "Communication" out of all potential speech-act properties of explanatory sentences can be fulfilled in the discourse of preaching. Therefore, it is natural to assume that the communicative intention of the speaker in the discourse, in general, is not verbal, contextual as such. It turns out to be the consequence of subordination of the speaker to some semantic rules resulting from the features of the discourse. It is the examples like (1-4) that are the reason for the generalization of the idea of statement reference in the discourse in terms of adsubjectification as a specific phenomenon of the discourse.

The main idea concerning the adsubjectification of the speaker owes its origin to the theory of the act of statement making proposed by the French School of Discourse Analysis (FSDA) (Area of meaning, 1990). Version of the French School of Discourse Analysis on this issue is in the theoretical framework of postmodernism - "the death of the subject." According to the French scholars, "the theory of statement ambiguous, it can be understood as a new statement of the Cartesian concept of the subject, the psychological subject, undivided subject having a command of their own language and communicative intentions and thus the absolute master of the meaning he wants to add to words. It is this last postulate, which is contested by the discourse analysis: one cannot be the absolute master of the meaning of statement; history and the unconscious bring their opacity in the naive idea of transparency of the meaning for the speaker as the subject" (Serio, 1999a).

FSDA, many provisions of which we rely on in this work, considers the syntactic analysis as a necessary component of the statement analysis. Regarding the syntactic analysis, there is the following general situation in the theory of the act of statement making: "The theory of the act of statement making (in French terminology enonciation) extends the purely syntactic analysis. This theory of different subjective layers in one statement, different sources of predicative relations in one statement, different subjects in one speaker allows detecting traces of the second statement 
that is reduced in rank and referred to but not pronounced, with the apparent uniformity and simplicity of the sentence" (Serio, 2003).

In §2 of the present work, we propose a methodology for such a syntactic analysis. In §3, an attempt to describe the statements that would provide that described statements are the projection of a variety of potential statements semantically acceptable in a sermon was made on its basis. In this task, the statements are analyzed in terms of the speech act, in which proposition and illocutionary act function as semantically related units, as well as in terms of the proposition, in which approved and unapproved propositions are the same semantically related units. Reference in these interactions is carried out on at least two subjective levels of statement: at the level of the illocutionary act relating to the propositional content of the sentence, and at the level of the propositional content relating to the outside picture of the world specific for this discourse.

\section{Method}

"Speech segments produced by the speaker, which are based on sentences generated by the system of elements and rules forming the language" are considered as statements (Lyons, 1978). Reference is reviewed through the structure of the statement. We rely on the well-known fact that the structure of almost any statement-result includes expressions, the reference of which is independent of the speaker. All non-assertive forms are these expressions. They are called so because they exist in the current statement as judgments not subject to approval by the speaker. A well-known example of these means of reference is nominalization. When expanding within a sentence, they, like the sentences, relate to the situation, say exactly what we need to understand them, but the things said are not approved by the speaker, and are assumed to be known (in traditional terms, these things known are referred to as the background knowledge or presuppositions) at the time of current statement making by the speaker.

For example, in the sentence (5)

(5) Just yesterday, we celebrated the triumphal Entry of the Lord into Jerusalem, the nominalization Entry is a "reduced clause" (6) with its verb-predicate:

(6) Lord entered Jerusalem in triumph.

The structural fact here is the following: the surface grammar of the statement-result is structural, consisting of two components: a group of approved and a group of approval. Referential relationship between them is not pragmatic, but structural. It reflects the syntagmatic characteristic of the statement: Celebrated (approval) and Lord entered Jerusalem in triumph (approved being equal to referent-fact) are units of statement structure, connections and relationships between them objectively are not pragmatic, but syntagmatic.

In many cases, things considered as a manifestation of subjective statement, activity of the speaker, and refer to the pragmatics, are in reality the requisite of the statement structure. We believe that the relationship of reference is, ultimately, also the relationship of semantic determination between the judgment of the speaker and the judgment of another subject in the structure of a single statement. The semantic effect of the reference mechanism examined through the structure of statement is defined by the direction of determination: the approved is semantically determining, as in the act of saying, it has an autonomous meaning; the logical value of the statement is determined with respect to the approved. Regardless of whether the speaker is expressed in the structure of the sentence by markers of personality or not, whether he uses the modal or descriptive statement, at the moment of syntactic connections of approval with the approved (permanent elements of the semantic-syntactic structure of the statement), he always relates his statement with the statement of another subject functioning in the current statement as an unapproved predication. In terms of FSDA, the process of correlating the approved predication with the unapproved one is called subordination of the subjectadsubjectification (Serio, 1999b).

Adsubjectification is the phenomenon of discourse, but not of pragmatics. Identification of the statements by the relation of adsubjectification does not provide the laws of construction of individual statements and their inner meaning; it provides the laws of construction of groups of statements, the "inter-subjective meaning" (Ajdukiewicz, 1999) reflecting the peculiarities of perception, knowledge of the reality and the nature of knowledge. To denote such groups of statements (identical in respect of perception of information and description of reality), this paper uses the term "discourse." The discourse means a special sub-language, subsystem within a popular language (Stepanov, 1995; Pereverzev, 1998) identified with the texts described in terms of a set of statements, a feature of which is that they are used to express a special mentality and ideology.

The first concept, on which the identification of the statements in the discourse is based, is the concept of semantic 
acceptability, the second one is the concept of truthful meaning of the sentence. There is one of the definitions of semantic acceptability: "The statement that is made or could be made by a native speaker in a suitable environment and is recognized or would be recognized by other speakers as belonging to the language in question, is acceptable" (Lyons, 1978). A phenomenon, which is subject to interpretation in terms of acceptability, is the propositional content of the statement. Statements, according to general understanding, have the same propositional content, if they have the same truth conditions. The propositional content is, thus, the meaning of the sentence truthful in the framework of one (some, particular) discourse; in another discourse it may have a different truthful meaning. In this sense, the propositional content is treated in this paper as a discursive meaning.

The propositional content of the sentence is set by analyzing the act of expression. In this paper, the method of investigation of the statement meaning is considered as the basis for the establishment of the discourse. The act of statement making refers to the process of propositioning leading to the formation of the statement as a voice message, i.e. judgment correlated with the reality in terms of acceptability and embodied in the form of any given sentence of the language system. According to the ideas of psycholinguists, propositioning refers to the level of deep semantic of the statement where the topic of the future statement is formed (the theme of the message), and information, which will be reported on this topic (the communicative core, rheme of the statement). "The presence of the topic and rheme implies the existence of two separate propositions" (Kasevich, 2007). This means that the surface grammar of the resulting statement can be presented as a structure including two components: the group of the approval (assertives) and the group of the approved (pre-assertives). Forms of the approval expression are predicates. Forms of expression of the unapproved predication are the grammatical forms with propositive semantics. An analysis of the statement-making act essentially repeats the synthesis of statement, but in a reverse order.

The syntactic analysis is complemented by performative taking into account the relationship between the act of speech of the subject of the statement act and the place and time of the approval of the predicative act. The performative analysis is based on the Performative Hypothesis, which not only explains the position of the speaker in the structure of the act of statement by deep performative position, but also demonstrates that the statement always has a binary structure. This is particularly important for the analysis of sentences with non-propositional meanings.

\section{Results}

\subsection{Ascriptive statements as products of adsubjectification}

Some statements represent only the pre-assertive part in terms of the grammatical form. They include statements constructed based on sentences that do not contain predicate statement forms in the surface structure. For example, in the sentence

(7) Let us, dear brothers and sisters, struggle on this blessed path to the best of our ability (Vladimir (Ikim), 2009).

The imperative form let us struggle is used that is not an assertive statement. Such sentences express the nonpropositional (in this case imperative) meaning. We call the statements, in which the surface form expresses a nonpropositional meaning ascriptives (non-referential expressions). The term "ascriptive" is not new and was used even by Strawson (1982 (1950)) to indicate the predicate use of a language expression (as opposed to a reference). Let us recall that "the most important from a logical point of view feature of an affirmative speech act or statement is that claiming some proposition, the speaker assumes responsibility for its truthfulness..." (Hilpinen, 1986). From this point of view, ascriptive statements are not defined by the truth conditions, and until recently, the works studying such sentences have offered only their pragmatic analysis: they demonstrated, in particular, what ascriptive sentences mean in accordance with their interpretation by the speaker or by the listener (Hilpinen, 1986; Kobozeva, 2004).

Ascriptive statements in the texts of sermons have absolute productivity. There are no texts of sermons, which contain none of these types of sentences at the same time, and in most of the texts, their simultaneous use is the dominant feature of the "grammatical form of the text". It can be shown experimentally, and we have done it the work (Burtsev, 2012), if the text misses sentences with non-propositional meanings, it, in general, cannot be a sermon. Ascriptives are formed on the grammatical basis of complex sentences with conditional clause, pronoun-correlative sentences with a correlation (undirected, with anaphoric connection of predicative units), simple imperative sentences, sentences with the predicate expressed by modal words, and sentences with the future perfect in sermons.

Ascriptives, as sentences, do not contain evidence of approval in the surface structure. However, if we assumed that the mechanism of the statements making was determined by the principle of binarity, not only descriptive statements, 
but also ascriptive, we would need to consider them having an assertive component that somehow appears in a part of the resulting statement. This means that the statements like (7) must have the same discursive structure as, say, the statements of examples (1)-(5). On this issue, our view is as follows. In accordance with the principle of binarity, a deep performative should be considered as the assertive. It takes the place of the main clause, the predicate of which contains signs of any illocutionary speech act in the model of statement. In other words, we see the mechanism of the statement making with ascriptives as the coupling of the illocutionary part with the ascriptive.

\subsection{Ascriptive statements based on imperative sentences}

As mentioned earlier, we considered Performative Hypothesis to be the solution to the problem of description of the statement model with an assertive component, which is outside the linguistic structure. It "lies in the fact that the latent (deep, semantic, etc.) structure always contains the sentence like "I + performative verb + recipient name + main proposition" as an "extra-principle preface" (Demiankov, 1986). According to the Performative Hypothesis, the assertive part in sentences with non-indicative meaning should be presented in the form of a performative verb, in the context of which the basic proposition looks like pre-assertive. The absence of an explicit performative in the surface structure is usually associated with indirect methods of the speech act performance (Demiankov, 1986). The concept of "the indirect method of the speech act performance" is associated only with facts of modification or even poverty in the surface structure of the sentence of the speech act, and is not associated with the communication objectives of the speaker.

An example of modification of the speech act is the splitting of the imperative sentences' semantics. This phenomenon is well known and is described in detail in the form of diverse meanings of will of imperative sentences (request, advice, please, etc.) (Austin, 1986; Russian grammar (I), 1980; Hrakovsky, 1990). Most often splitting of imperative meaning is represented in such a way that the surface and the deep structure of the imperative sentence are described with different predicates that differ in their illocutionary functions.

The in-depth structure of sentences with explicit performative is the main sentence with the performative verb and the embedded clause (Searle, 1986). The deep structure for the performative-directive should look like this: "I verb you + you Future verb (NP)" (Searle, 1986). Example by Searle: "Sentence I command you to leave is a surface implementation for the structure: I command you + you will go" (Searle, 1986)). The formalization proposed by Searle is designed to explicitly performative sentences, with explicitly expressed performative in the surface structure. It reveals the full synonymy between the deep and the surface structures. Let us now compare this example with our material. The verbs in the imperative form, which are not performatives in the language system, should be transferred to explicit performatives (Mac Coley, 1981; Hrakovsky, 1990).

(8) Heed with the fullness of the soul to today's Gospel reading.

The in-depth structure should be as follows:

(8a) I command you + you will heed (the Gospel reading).

It is obvious that this structure neither in its performative part, nor in part of the contents of the embedded clause is semantically reduced to the surface structure. The following deep structure will be acceptable for the text of the preaching:

(8b) I request /suggest, recommend, caution, recommend, urge, beg / (you) + you to heed (the Gospel reading).

The in-depth structure of the imperative statements in a sermon looks as follows: "I + Exesertive + Pronoun + Complementator + Past tense of the verb + (nominal group)". During the semantic transformation a replacement of directive by exesertive takes place (Austin, 1986), the future by the past, and the subordinative conjunctioncomplementator-is added. Without subordinative conjunction, the in-depth structure is non-grammatical.

If the original statement is an explicit performative (I command to heed to the Gospel reading), then there is a complete correspondence between the surface and the in-depth structures. But there are no statements in sermons formed by imperative sentences-orders. Compare the following examples:

(9) Believe, Brethren, in the name of the Lord Jesus with all your heart; confess Him with blameless boldness; keep His commandments with love; expect His glorious coming with burning lamps of knowledge of God, and oil of mercy for others-take the fruit of righteousness-salvation. Amen (lliodor and Bishop, 1839). Let us, my Brethren, always keep 
our confession with dedication and work for the Lord with the flame and constant love for Him (Leontius and Archbishop, 1876). Therefore, the more you work for the Lord, the more be careful not to lose accumulated in a lifetime in a moment! (Reznikov, 1995). Beware the deadly error! Let us now fear the denial of Christ coupled with mistake! Let us now fear the loss of true salvation for the assimilation of false ideas, hostile Faith! (St. Ignatius Bryanchaninov, 2011).

The issue of the status of the deep notion for statements can be controversial as a part of the performative hypothesis, namely: whether the in-depth structure reflects the actual process of statement generating when the statement serves as a functional element of a particular text or group of texts; or representation of the in-depth structure is just a way of semantic description of the sentences extracted from the text as certain elements of the language system. In our view, establishment of the correspondence between the performative meaning and the meaning of the statement is hardly possible without addressing the inserted context, which is an embedded clause in the in-depth structure. For example, none of the imperative sentences in a sermon cannot be interpreted outside the embedded clause, predicate of which, as applied to the semantic rules of the discourse, is converted into the conjunctive mood. Meanwhile, for the imperative sentence, taken out of context, interpretation with the future tense of the predicate of embedded clause is equally permissible:

(10) Drop the wine.

(10a) I command you + you will not drink the wine.

Illustration (10-10a) is based on an example (11) for which the directive turns out to be an unacceptable meaning as a performative under the genre of the sermon.

(11) Recover yourself, drop the wine, get away from the temptation, do not compass others to wine! (Abbot Roman (Zagrebnev), 2007).

(11a) *I command you + you will recover yourself, drop the wine, get away from the temptation, will not compass others to wine.

(116) I ask you to recover yourself, no to drink the wine, get away from the temptation, do not compass others to wine.

Such judgments as (11b) and the like are displayed, if the process of statement making is considered with reference to the discourse. It follows that it is necessary to consider the "indirect method of the speech act performance" in case of the imperative statement in a religious discourse to be determined not by communicative purposes, but by the nature of referential relationship between the components of the discourse structure. If the admissibility of illocutionary force is consistently defined only in relation to the pre-assertive, such a definition is only possible in the moment of its coupling with pre-assertive.

\subsection{Ascriptive statements based on sentences with the future perfect}

For the future perfect, we present the in-depth structure, in which representatives are performative predicates (according to the classification of Searle (1986), and according to the classification of Austin, "predict" is an expositive (Austin, 1986): "I + Representative + Complementator + Main proposition". For example:

(12) This faith in the future life will change for each of us with the vision of Him in Whom we believe.

(12a) I predict, (that) instead of the faith in future life will be the vision of Him in Whom we believe.

Compare sentences from the group (13).

(13) The life where imaginary earth triumph will be replaced with eternal sorrow will begin and temporary humiliation and suffering will be replaced with eternal joy and glory of the Lord (Nicholas, 1957). The Lord will wipe away the tears from the eyes of men, and there will be no memory of the affliction, of diseases, of sorrows which human soul has suffered in this life (Nicholas, 1957). There will come a day when the Lord God will manifest himself only in the light of His truth (Nicholas, 1950). Thence, dear brothers and sisters, striving hard in the field of struggle with sin through repentance, we will become trim for our heavenly Father (Kirill (Pavlov) and Archimandrite, 2000).

Sentences with the future perfect are usually interpreted within the functional-semantic category of potentiality (invalid inclination) (Bondarko, 1990). For the discourse of the sermon, the potentiality is equal to reliability, so the potentiality finds its justification through the category of reality and cannot be paired with unreality. The interpretation of the future perfect through the unreal cannot be made in the discourse of the sermon, above all, because of the concept of 
FAITH excluding any guessing of the future on the part of the speaker (although syntactically the deep structure with the representative also looks like unreal). If the sermon expresses a sentence like (14), then (14a) after the representative should be considered as a statement functionally similar to pre-assertive-fact.

(14) Our cunning always turns to our shame (Reznikov, 1995).

(14a) I predict + we will always be confounded due to our cunning.

The following material will help to explain these examples. All pre-assertive forms have one thing in common in the mechanism of statement making: they represent the predicative relation, which is established to the point where the speaker expresses this sentence. This is quite clearly seen in the context: ascriptives are a kind of pre-assertive forms in the text of the sermon. Sentence (14) is closely connected with the previous context. Here is a part of this context, let us give it numbers (15) and (16):

(15) The Apostle writes in his letter to the Romans: "God is faithful. And every man a liar". And Prophet David testifies: "There is none righteous; there is no one who understands; no one seeks for God; they have all gone out of the way, become outcast"... And today we see how the Apostle has to say in the face of this universal human infidelity. Thus, he must prove even to the sons of God's chosen people that they will be vain to hope for their election and on circumcision as an external sign of the election, if their hearts will not belong to God... The fact that the wicked man in general values the external signs as long as they are signs of the election and domination; but as soon he begins to feel that they are signs of authority and responsibility, he immediately goes to the other extreme: he begins to assert that the external is nothing, and the soul is the only importance... Our cunning is infinite... "God is faithful" to His creation. This faithfulness is visible everywhere and in everything. Even to people who are not yet redeemed and reconciled with God he says: "do not be anxious and do not say: "what shall we eat?" or: "what shall we drink?" or: "what shall we wear?"... because Your heavenly Father knows you have need of all these...

(16) Our cunning will always turn to our shame (Reznikov, 1995).

If we add a performative verb to (16), the conditions of its use will be the information, which is assumed true in (15) and which is repeated in (16) as the following summary: If we are cunning, we will always be confounded. The performative is superfluous for the judgment we are cunning and is unacceptable for the judgments we will be confounded. Consequently, the performative refers to the sentence as a whole describing it in an act of expression as the ascriptive.

Thus, ascriptives (in particular, in the future perfect form) are sentences relating to the preceding text. Compositionally and logically, these are always the structures, which cannot be the beginning of the text or the test unit, but they can complete the texts naturally and their compositional and stylistic or syntactic units. From this point of view, ascriptives serve as a means to make the statements (perform reference to the fact), although they are not the descriptive statements.

\subsection{Ascriptive statements based on contingent, comissive and correlative sentences}

All ascriptives can be viewed according to their compositional role in the text as logical consequences. In this case, if all of them are pre-assertive forms, their purpose (despite the grammatical nature of mode and implicative sentences) is to characterize the discourse referents as the data itself in the world of things.

A composite approach to assessing referential properties of ascriptives is relevant in the light of the following facts. For a number of allied means of communication, including consecutive, the literature presents their interpretations in the form of metatext operators having the implicit mode of "speaking." Such interpretations are proposed by Wierzbicka. For example, "therefore (Igitur)" can be interpreted as "I will speak" (Wierzbicka, 1978). It is believed that metatext connection operators in the texts of sermons have characteristic performative tone. This applies to both productive metatext operators in the sermons: parenthetical word therefore (Igitur) and pronominal adverb thence. It only remains not clear, to which performative (assuming that I say is not a performative (Apresyan 1995)) their use is equal. Compare:

(17) Therefore, brothers and sisters, [performative] exhortation and eschewing of the Baptist are very necessary for us (Gregory, archbishop, 1853). Therefore, brethren, [performative] if Jesus Christ had not even brought us nothing more than what He gave us with the light of His teachings; already for that alone we should forever thank Him with all the soul day and night (Gregory, archbishop, 1853). Therefore, [performative] who does not want to be blind, he must hold firm with St. Church - Orthodox, for in it the pure truth is (Leontius, archbishop, 1876). 
Paducheva (2003) proposes an effective formal way to distinguish the semantics of propositional verbs-based on their compatibility with the indirect question. We use this method to determine the value of illocutionary ascriptive. While illocutionary verb "I communicate" is semantically acceptable in the constructions, the ascriptive operates with reference to the fact; while the construction contains illocutionary verb "I assent", the ascriptive operates with the reference to the proposition or event.

1) In the comissive statements, the verb "I communicate" should be considered as performative:

(18) Therefore, brothers and sisters [? I assent, communicate], exhortation and eschewing of the Baptist are very necessary for us

(18a) *Therefore, brothers and sisters [l assent], whether we need exhortation and eschewing of the Baptist.

(18b) Therefore, brothers and sisters [I communicate], whether we need exhortation and eschewing of the Baptist.

2) The type of the performative for conditional sentences is defined additionally by the predicate type of the main part of the paraphrase. If the main clause contains the comissive predicate, the performative is "I communicate" (19a); if the main clause contains the imperative, the performative is "I Ask" (20b); and if the main clause contains the indicative, the performative is "I communicate" (20a).

(19) Thence, we, if being harassed due to the faith, should rejoice more

(19a) I communicate whether we should rejoice more, if being harassed due to the faith.

(20) Thence, if you know the Lord is holy, try to be holy yourself (Kirill (Pavlov), archimandrite, 2000).

(20a) * Thence [l assent, communicate], whether you will try to be holy yourself, if you know the Lord is holy.

In (20a), the main proposition whether you will try to be holy yourself, if you know the Lord is holy is characterized by an uncertain truth meaning. You cannot answer yes or no. They are like imperative sentences, which can be interpreted only through performative "I ask" in the semantic representation:

(20b) Thence [l ask], be holy yourself, if you know the Lord is holy.

According to all the semantic descriptions, the request presumption includes proposition, the contents of which motivates the request. The presumption of the sentence (21) is its negative proposition (22).

(21) Be holy.

(22) You are not holy.

Negative propositions in all cases are an expression of the fact.

3) Correlative sentences like (23) are in all ways similar to the conditional (Mitrenina, 2008)

(23) He who loves the God, this man's mind is controlled by the grace of God and subtly sees all the machinations of the enemy (Saint Silouan, 1998).

(23a) I communicate, if the man loves the God, this man's mind is controlled by the grace of God.

\section{Conclusion}

We have reviewed the peculiarities of statements' references in the discourse of the sermon, using sentences with nonpropositional meaning (ascriptives) as a base material. An analysis of these sentences and comparison of their referential with the sentences expressing the propositional meaning showed that the ascriptives in the sermons are functionally similar to the pre-assertives, although their grammatical properties are the sentences with a subjective mode. This conclusion applies to all types of the considered sentences with non-propositional meaning. Adsubjectification is defined as the submission of the speaker to the subject of the pre-assertive and finds expression in the speech-act properties of the sentences. The speech act of the speaker in the discourse of the sermon can only be "Communication" as a result of semantic determination of the assertive. Just as in the case of descriptive statements, the referential role of nondescriptive statements in the discourse of the sermon consists in the reference to the facts, but not to the events or propositions.

Referential properties of the statements in the discourse of the sermon and, obviously, in any other discourse are unrelated to the pragmatic context and the subject of speech activity as with a carrier of certain psychological (will, emotion, opinion) and (in part) social characteristics and are explained in terms of an act of statement making by the 
means of adsubjectification concept.

It is believed that adsubjectification and reference to the facts are essential for the implementation of communicative functions by the statements of religious language: communication (informing) and influence at the same time. If this were not so, the implementation of the rhetorical principle of persuasion would be impossible for religious statements.

\section{Acknowledgements}

The study is carried out within the framework of the scientific and methodical works included in the state order of the Ministry of Education and Science of the Russian Federation in 2015.

\section{References}

Ajdukiewicz, K. (1999). lazyk I smysl [The language and meaning]. Logos, 7, 67-93. Retrieved from http://www.ruthenia.ru/logos/number/ 1999-07-17.htm [in Russian].

Apresian, lu.D. (1995). Selected works, Vol. 2. Integral description of language and systemic lexicography (pp. 767). Moscow: School "Languages of Russian Culture" [in Russian].

Area of meaning: The French school discourse analysis (1999, pp. 416). Moscow: IG of "Progress".

Arutiunova, N.D. (2002). The proposal and its meaning (logical-semantic problems) / N.D. Arutyunova (Ed. 2nd, stereotypical, pp. 384). Moscow: Editorial URSS [in Russian].

Arutiunova, N.D. (1982). Linguistic problems of references. New in foreign linguistics. Vol. XIII. Logic and linguistics (the problem of reference) (pp. 5-42). Moscow: "Rainbow" [in Russian].

Austin, J.L. (1986). Word of the action. New in foreign linguistics. Vol. XVII. The theory of speech acts (pp. 22-130). Moscow: Progress.

Authier-Review, J. (1999). Explicit and constitutive heterogeneity: the problem in a different discourse. Area sense: French school of discourse analysis (pp. 54-94). Moscow: IG of "Progress" [in Russian].

Benveniste, E. (2002). General linguistics (pp. 448). Moscow: Editorial URSS [in Russian].

Bondarko, A.V. (1990). The reality / unreality and potentiality. The theory of functional grammar. Temporality, modality (pp. 72-79). Leningrad: Nauka [in Russian].

Burtsev, V.A. (2012). The discourse of the Russian Orthodox sermon production methods statements (Doctoral dissertation), Yelets, pp. 447 [in Russian].

Burtsev, V.A. (2014). The use of complex sentences in a scientific reason and religious and sacred styles of modern Russian (pp. 167172). Actual problems of modern linguistics and language teaching methodology: Proceedings of the All-Russian Conference on the 115th Anniversary of the Birth of Professor I.A. Figurovskii, Yelets: Bunin YSU [in Russian].

Burtsev, V.A. (2013). Ligamental sentence in the text of the Russian Orthodox preaching as a phrasal expression (pp. 285-289). Cognitive factors phraseology interaction with related disciplines: Proceedings of the Sat. scientific. tr. in the III Intern. scientific. Conf. (Belgorod, 19-21 March 2013). Belgorod: ID "Belgorod" NIU "BSU" [in Russian].

Chimik, V.V. (1990). Category subjectivity and its expression in Russian (pp. 184). Leningrad: Publishing House of Leningrad University [in Russian].

Davison, A. (1986). Linguistic and pragmatic description: Reflections on "The paradox performative." New in foreign linguistics, Vol. XVII. The theory of speech acts (pp. 235-269). Moscow: Progress [in Russian].

Demiankov, V.Z. (1986). "The theory of speech acts" in the context of modern foreign language literature (Review directions). New in foreign linguistics, Vol. XVII. The theory of speech acts (pp. 223-234). Moscow: "Progress" [in Russian].

Demiankov, V.Z. (1981). Pragmatic bases interpretation statements. Proceedings of the Academy of Sciences of the USSR. A series of literature and language, Vol. 40, 4, 368-377 [in Russian].

Demiankov, V.Z. (1983). Understanding how to interpret the activities. Questions of Linguistics, 6, 58-67. [in Russian].

Hilpinen, R. (1986). Semantics imperatives and deontic logic. New in foreign linguistics, Vol. XVIII. Logical analysis of natural language (pp. 300-317). Moscow: Progress [in Russian].

Hrakovsky, V.S. (1990). Imperative. The theory of functional grammar. Temporality. Modality (pp.185-243). Leningrad: Nauka [in Russian].

Jacobson, R.O. (1972). Shifters, verbal categories and Russian verb. Principles of the typological analysis of languages of different order (pp. 95-113). Moscow: Nauka [in Russian].

Karttunen, L. (1985). Logic English designs with sentential complement. New in foreign linguistics, Vol. XVI. Linguistic pragmatics (pp. 303-332). Moscow: "Progress" [in Russian].

Kasevich, V.B. (2007). Semantics. Syntax. Morphology. Actual problems of modern linguistics: studies. Allowance (L.N. Churilina, Comp., 2nd ed., Rev, pp. 344-36). Flinta Moscow: Nauka [in Russian].

Kobozeva, I.M. (2004). Linguistic Semantics: the textbook (Ed. 2nd, pp. 352). Moscow: Editorial URSS [in Russian].

Kopotev, M.V. (2008). Principles of syntax of idiomatization (Doctoral dissertation, pp. 52). Helsinki University. Retrieved from: http://www.helsinki.fi/ kopotev/kopotev_principles_of_synt_idiomatization.pdf [in Russian].

Linskii, L. (1982). Reference and referents. New in foreign linguistics, Vol. XIII. Logic and linguistics (the problem of reference) (pp. 161- 
178). Moscow: "Rainbow" [in Russian].

Lomtev, T.P. (1958). Basic syntax of the Russian language (pp. 166). Moscow: Uchpedgiz [in Russian].

Lyons, J. (2003). Linguistic Semantics: An Introduction (pp. 400). Moscow: Languages Slavic culture [in Russian].

Lyons, J. (1978). Introduction to theoretical linguistics (pp. 544). Moscow: Progress [in Russian].

Mac Coley, J.D. (1981). The place of semantics in the grammar. New in foreign linguistics, Vol. H. Linguistic semantics (pp. 235-301). Moscow: Progress [in Russian].

Mitrenina, O.V. (2008). Syntax correlative structures of the Russian language from the standpoint of generative grammar. Proceedings of the International Conference "Dialogue 2008". Retrieved from http://www.dialog-21.ru/dialog2008/materials/htm//55.htm [in Russian].

Paducheva, E.V. (2003). Deducible whether the ability to subordinate an indirect question of semantics of words?. Logical analysis of language. Favorites. 1985-1995 (pp. 68-78). Moscow: Indrik [in Russian].

Paducheva, E.V. (1996). Semantic Research (semantics time and type in the Russian language; semantics of narrative) (pp. 464). Moscow: School "Languages of Russian Culture" [in Russian].

Paducheva, E.V. (1985). The statement and its relation to reality (referential aspects of semantics of pronouns) (pp. 276). Moscow: Nauka [in Russian].

Pereverzev, K.A. (1998). Saying the situation: the ontological aspect of philosophy of language. Issues of Linguistics, 5, 24-52. [in Russian].

Piers, C.S. (1983). From the work "Elements of logic. Grammatica speculative". Semiotics (pp. 151-210). Moscow: Raduga [in Russian].

Rachilina, E.V. (2010). Linguistics constructions (E.V. Rachilina, Ed., pp. 584). Moscow: Publishing center" Azbukovnik" [in Russian].

Russian grammar, Vol. 1. Phonetics. Phonology. Stress. Intonation. Word formation. Morphology (1980, pp.789). Moscow: Nauka [in Russian].

Savova, D.V. (2012). Predicative structure of statements in Bulgarian. Issues of Linguistics, 3, 69-90. [in Russian].

Searle, J.R. (1986b). The classification of illocutionary acts. New in foreign linguistics, Vol. XVII. The theory of speech acts (pp. 170194). Moscow: Progress [in Russian].

Searle, J.R. (1986a). What is a speech act. New in foreign linguistics. Issue XVII. The theory of speech acts (pp. 151-169). Moscow: Progress [in Russian].

Serio, P. (2003). Comparison of the identity and the implicit predication. Logical analysis of language. Favorites. 1985-1995 (pp. 282295). Moscow: Indrik [in Russian].

Serio, P. (1999a). How to read texts in France. Area sense: French school of discourse analysis (pp. 12-53). Moscow: IG of "Progress" [in Russian].

Serio, P. (1999b). Russian language and Soviet political discourse analysis: analysis of nominalization. Area sense: French school of discourse analysis (pp. 337-383). Moscow: IG of 'Progress' [in Russian].

Sokolovskaya, K.A. (1993). Aspectual characteristics of pragmatic interpretation statements. Issues of Linguistics, 5, 59-69 [in Russian].

Stepanov, Iu.S. (1981). In search of pragmatics (The problem of the subject). Proceedings of the Academy of Sciences of the USSR. A series of literature and language, Vol. 40, 4, 325-332 [in Russian].

Stepanov, lu.S. (1995). Alternative world discourse, the fact and the principle of causality. Language and science of the late 20th century (pp. 34-72). Moscow: Institute of Linguistics [in Russian].

Strawson, P.F. (1982). About references. New in foreign linguistics, Vol. XIII. Logic and linguistics (the problem of reference) (pp. 55-86). Moscow: Raduga [in Russian].

Strawson, P.F. (1986). Intention and convention in speech acts. New in foreign linguistics, Vol. XVII. The theory of speech acts (pp. 131150). Moscow: Progress [in Russian].

The theory of functional grammar. Temporality. Modality (1990, pp. 264). Leningrad: Nauka [in Russian].

Wierzbicka, A. (1978). Metatext text. New in foreign linguistics, Vol. VIII. Text Linguistics (pp. 402-424). Moscow: "Progress" [in Russian].

Wierzbicka, A. (1985). Speech acts. New in foreign linguistics. Vol. XVI. Linguistic pragmatics (pp. 251-275). Moscow: "Progress" [in Russian].

Zeitlin, S.N. (1990). Necessity. The theory of functional grammar. Temporality. Modality (pp. 142-156). Leningrad: Nauka [in Russian].

\section{The Texts of Sermons}

Abbot Roman (Zagrebnev) (2007). I'm learning to preach. Book Three. Sermons, teachings, spiritual poetry / novel (stroke), the abbot (pp. 208). Pskov [in Russian].

Gregory, arihiepiskop Kazan and Sviyazhsk (1853). Words or conversations on all Sundays and public holidays in the year, with prisovokupleniem words and speeches of some special cases, said a member of the Synod, Archbishop Gregory Kazan and Sviyazhsk, Vol. II (pp. 363). St. Petersburg: Gregory arihiepiskop Kazan and Sviyazhsk [in Russian]..

lliodor, Bishop (1839). Verbal with milk or collection of words, spoken to the Kursk lliodor flock, Bishop Kursk and Belgorod. Part of the first and second (Part 1 - pp. 195; Part 2 pp. 167). St. Petersburg: Heliodorus, Bishop of Kursk and Belgorod [in Russian].

Kirill (Pavlov), Archimandrite (2000). Time of Repentance. Sermons (pp. 189). Moscow: Publishing house of the Moscow Representation of the Trinity-Sergius Lavra [in Russian].

Leontius, Archbishop of Warsaw and Chelm (1876). Word, teachings and speeches Leonty, Archbishop Holmskago and Warsaw. Issue three times, considerably enlarged. (Vol. I, pp. 368). St. Petersburg: Leontius, Archbishop of Warsaw and Chelm [in Russian]. 
Menetrov M., a priest (1905). Pastoral instruction. Festive teaching (pp. 184). Moscow: The publication of the magazine "Sunday Afternoon" [in Russian].

Nicholas, Metropolitan (1950). Word of the question, that is. II- IV. Vol. 2. Words and speeches (1947-1950.) (pp. 400). Moscow: publication of the Moscow Patriarchate [in Russian].

Nicholas, Metropolitan (1957). Word of the question, that is. II- IV. - Vol. 4 (Words, speeches and articles. (1954-1957.) (pp. 472). Publication of the Moscow Patriarchate [in Russian].

Saint Silouan (1998). Silouan (pp. 464). Moscow: Publishing House "Summer" [in Russian].

St. Ignatius Bryanchaninov (2011). Word of the person (pp. 720). St. Petersburg: St. Ignatius Parish Brianchaninov [in Russian].

Vladimir (Ikim), metropolitan (2009). The gates of repentance: Words spoken at different times during the singing of the Lenten Triodion (pp. 925). Moscow: Siberian Blagozvonnitsa [in Russian].

Reznikov, V. (1995). One hundred and sixty-four sermons daily church Apostolic Gospel and read from the Passover (pp. 368). Moscow: Publishing House of the Brotherhood of St. Alexis [in Russian]. 